\title{
The Professional Quality of Life for Healthcare Workers During the COVID-19 Pandemic in Turkey and the Influencing Factors
}

\section{Türkiye'de COVID-19 Salgını Döneminde Sağlık Çalışanlarında İş Yaşam Kalitesi ve Bunu Etkileyen Faktörler}

\section{(D) Ayşegül YILMAZ1', iD Fatma BAY22, id Özlem ERDEM³, id Birol ÖZKALP4}

'Konya Beyhekim Training and Research Hospital, Clinic of Emergency, Konya, Turkey

${ }^{2}$ KTO Karatay University, Faculty of Health Sciences, Konya, Turkey

${ }^{3}$ KTO Karatay University, Health Services Vocational School, Konya, Turkey

${ }_{4}^{4}$ KTO Karatay University Faculty of Medicine, Konya, Turkey

\begin{abstract}
Objective: It is very important to ensure the professional quality of life of healthcare workers in combating the coronavirus disease- 19 (COVID-19) outbreak. It is therefore necessary to determine what factors may lead to compassion satisfaction (CS), burnout (BO) and compassion fatigue (CF) in order to ensure the professional quality of life in healthcare workers, and to develop institutional and national strategies and policies to eliminate these factors. Therefore in this study, we aimed to determine the levels of CS, BO and CF among healthcare workers during the COVID-19 pandemic, as well as the influencing factors.
\end{abstract}

Methods: A descriptive, descriptive-relational and cross-sectional study was conducted, using the Professional Quality of Life scale, with 796 Turkish healthcare workers after the emergence of the COVID-19 pandemic. In the study, the Professional Life Quality of healthcare workers was examined in three dimensions including $\mathrm{CS}, \mathrm{BO}$ and $\mathrm{CF}$.

Results: The results indicated that while $77.8 \%$ of healthcare workers were above the mean CS level, $62.8 \%$ of them were below the mean $\mathrm{BO}$ level and $87.3 \%$ of them were below the mean CF level. Their title, department, professional working year and workmates' diagnosis with COVID-19 were found to affect the CS, $\mathrm{BO}$ and $\mathrm{CF}$ of healthcare workers.

\section{ÖZ}

Amaç: Koronavirüs hastalığı-19 (COVID-19) salgını ile mücadelede sağlık çalışanlarının iş yaşam kalitesinin sağlanması oldukça önemlidir. Bu nedenle sağılk çalışanlarında iş yaşam kalitesini sağlamak için merhamet tatminine, tükenmişliğe ve merhamet yorgunluğuna hangi faktörlerin yol açabileceğini belirlemek gerekir. Bu nedenle bu çalışmada, COVID-19 salgını döneminde sağlık çalışanlarının mesleki tatmin, tükenmişslik ve eş duyum yorgunluğu düzeylerinin ve bunları etkileyen faktörlerin belirlenmesi amaçlanmıştır.

Yöntemler: Bu çalışsma, COVID-19 pandemisinin ortaya çıkmasının ardından 796 Türk sağlık çalışanı ile Profesyonel Yaşam Kalitesi Ölçeği kullanılarak tanımlayıcı-ilişkisel ve kesitsel olarak yapılmışıır. Çalışmada, sağlık çalışanlarının Profesyonel Yaşam Kalitesi mesleki tatmin, tükenmişlik ve eş duyum yorgunluğu olarak üç boyutta incelenmişstir.

Bulgular: Sonuçlar, sağlık çalışanlarının $\% 77,8$ 'inin ortalama mesleki tatmin düzeyinin üzerinde olduğunu, $\% 62,8^{\prime}$ 'inin ortalama tükenmişlik düzeyinin altında ve $\% 87,3$ 'ünün ise ortalama eş duyum yorgunluğu düzeyinin altında olduğunu göstermiştir. Sağlık çalışanlarının mesleki tatmin, tükenmişlik ve eş duyum yorgunluğu üzerinde unvan, çalş̧ılan birim, mesleki çalışma yilı ve
Address for Correspondence: Ayşegül YILMAZ, Konya Beyhekim Training and Research Hospital, Clinic of Emergency, Konya, Turkey

E-mail: yaysegul78@gmail.com ORCID ID: orcid.org/0000-0002-3102-4238

Cite this article as: Yılmaz A, Bay F, Erdem Ö, Özkalp B. The Professional Quality of Life for Healthcare Workers During the COVID-19 Pandemic in Turkey and the Influencing Factors.

Bezmialem Science 2022;10(3):361-69

${ }^{0}$ Copyright 2022 by the Bezmiâlem Vakıf University

Bezmiâlem Science published by Galenos Publishing House.
Received: 28.12 .2020

Accepted: 21.04.2021 
Conclusion: We found that workers had good levels of CS and low levels of $\mathrm{BO}$ and $\mathrm{CF}$ during the study period. Therefore, we can say that the quality of work life is good. However, due to the increase in the number of cases, we recommend that the study be repeated in future, to continuously evaluate the psychological state of healthcare workers and, using the resulting comparisons, to implement the necessary arrangements timeously.

Keywords: COVID-19 pandemic, healthcare workers, professional quality of life, influencing factors mesai arkadaşının COVID-19 tanısı alma durumunun etkili olduğu bulunmuştur.

Sonuç: Sonuç olarak, çalışmanın yapıldığı zaman diliminde sağlık çalışanlarının mesleki tatmin düzeylerinin iyi olduğunu, tükenmişliğin ve eş duyum yorgunluğunun düşük olduğunu, dolayısıyla iş yaşam kalitesinin iyi olduğunu söyleyebiliriz. Ancak olgu sayılarının artması nedeniyle çalışmanın ilerleyen zamanlarda tekrarlanması, sağlık çalışanlarının psikolojik durumunun sürekli değerlendirilmesi ve karşılaştırmaların yapılarak gerekli düzenlemelerin bir an önce hayata geçirilmesi önerilmektedir.

Anahtar Sözcükler: COVID-19 salgını, sağlık çalışanları, iş yaşam kalitesi, etkileyen faktörler

\section{Introduction}

The Coronavirus disease-19 (COVID-19) emerged in Wuhan, China in December 2019 and led to a global pandemic. The World Health Organization (WHO) declared the COVID-19 outbreak a public health emergency of international concern on 30 January 2020 (1). The first case of COVID-19 in Turkey was observed on 11 March 2020, and it quickly became a pandemic in the country.

Although the WHO and public health officials all over the world have tried to control the COVID-19 pandemic, the rapid spread and severe clinical course of the virus have made the fight against the pandemic difficult and protracted (2). The most important tasks in this struggle undoubtedly fall to healthcare workers.

Healthcare workers have been adversely affected by long working hours and difficult working conditions during the pandemic, the disease's rapid transmission and the high mortality rate, fears of contracting COVID-19 and passing it on to their families and prolonged separation from loved ones (3-7). These reasons cause healthcare workers to have burnout (BO) and compassion fatigue $(\mathrm{CF})$, which lead healthcare workers to develop severe mental problems such as depression and anxiety $(1,8-11)$. These problems cause the compassion satisfaction (CS) of healthcare workers to decrease, and ultimately, the quality of their working life also decreases.

Research has indicated that CS decreases in healthcare workers who constantly experience BO and CF $(12,13)$, and this causes a decreased health service performance and quality of patient care, and negative job attitudes, while also increasing service delivery costs and the number of staff who think of quitting their jobs (14). Therefore BO, CF and CS are important factors that affect the fight against the pandemic and need to be addressed immediately.

The WHO, highlighting the excessive burden on healthcare workers during the pandemic, called for action to address urgent needs and measures to save lives and prevent serious adverse effects on the physical and mental health of healthcare workers (2). Therefore, in this study, we investigated the CS, BO and CF levels of healthcare workers during the COVID-19 pandemic and examined influencing factors.

\section{Methods}

\section{Study Design and Setting}

A descriptive cross-sectional online survey design and a quantitative research method were used. With permission obtained, a copy of the survey was converted into an online survey using one of the free survey websites, and a link to it was shared on social media platforms (Facebook, Instagram and Twitter) and WhatsApp groups that included healthcare workers. The data were collected between 25 and 30 June 2020. The participants responded to the survey after agreeing to participate in the study. Surveys were completed after data entry were deleted from the website. The researcher protected against multiple uses by exporting the data.

\section{Sample Size and Sampling}

Healthcare workers working in healthcare services constituted the population of our study. According to the latest data announced by the Turkish Statistical Institute (15), there were 160,810 doctors, 198,103 nurses, 55,972 midwives and 182,456 other medical staff in 2019 in Turkey. The other medical staff group includes healthcare personnel employed in fields including surgery, anaesthesia, environmental health, dental prosthetics, dentistry, physiotherapy, first and emergency aid, biology, child development, dietetics, laboratory work and audiometry.

With the population known, it was sufficient to reach at least 384 healthcare workers with a confidence interval of $95 \%$ by using the sample calculation formula. This study reached 796 healthcare workers using the online survey method. Since there was no existing data on the prevalence of quality of life, $\mathrm{p}$ and q-values were taken as 0.5 .

\section{Data Collection Tool}

The online survey form consisted of 12 questions investigating the sociodemographic and working style of the study participants, and 30 questions from the Professional Quality of Life scale.

\section{Demographic and Work-Related Information Form}

The researchers prepared the survey in accordance with the literature $(16,17)$. It consisted of questions related to respondents' age; gender; marital status; title; department; professional, weekly 
and daily working hours and the pandemic. It also included questions about providing care for COVID-positive patients during the COVID-19 pandemic and being diagnosed as having COVID-19.

\section{Professional Quality of Life Scale}

The Professional Quality of Life scale was developed by Stamm in 2005 (18), and its validity and reliability in Turkish studies were confirmed by Yeşil et al. (16) in 2010. This scale is a selfreport evaluation tool consisting of 30 items and three subscales. The items are evaluated on a six-step chart ranging from "never" (0) to "very often" (5). Three subscales consist of CS (10 items), BO (10 items) and CF (10 items) parts. Higher scores obtained from each dimension indicate higher levels of CS, BO and CF, respectively. The minimum and maximum scores obtained from the scale are zero and 50 points, respectively. The Turkish version of the scale has CS.87, BO.72 and CF.80 Cronbach's alpha values, respectively (16). In this study, the Cronbach's alpha coefficient was found to be 0.88 for CS, 0.70 for $\mathrm{BO}$ and 0.84 for $\mathrm{CF}$,

\section{Statistical Analysis}

The SPSS 24.0 statistical package programme was used for statistical analysis of the data. Descriptive statistics were used while investigating the prevalence of CS, burnout and CF within the data on demographic and working styles. The independent samples t-test and one-way analysis of variance (ANOVA) were used as parametric tests; the Kruskal-Wallis and Mann-Whitney $\mathrm{U}$ tests were used as nonparametric tests. Skewness and kurtosis values were required to be between +1.5 and -1.5 to evaluate the homogeneity of variance (19). Pearson's correlation analysis was used for the prediction results. The results were evaluated at a confidence interval of $95 \%$ and a significance level of $\mathrm{p}<0.05$.

\section{Ethical Considerations}

Permission was obtained for the study from the Ministry of Health (2020-05-21T15_40_06) and KTO Karatay University Medicine and Non-Medical Device Research Ethics Committee (2020/023).

\section{Results}

The demographic characteristics of the participants and the descriptive statistics of their working conditions are presented in Table 1. Most of the healthcare workers were female, married and between the ages of 36 and 45 . While $39.57 \%$ of the study participants were nurses, $45.73 \%$ of them worked in departments unrelated to COVID-19. Of the participants $38.57 \%$ had been working in their fields for between six and ten years. Furthermore, while $28.26 \%$ of the healthcare workers participating in the study worked for more than 45 hours a week, participants working eight hours a day were in the majority (60.05\%), while day and shift workers were almost equal in number. While $50.13 \%$ of the participants were providing service (care) for COVID-19 positive patients, $98.49 \%$ of them were not diagnosed as having COVID-19. Of the study participants, $56.28 \%$ reported that their workmates were not diagnosed as having COVID-19 either (Table 1).
The mean scores of the dimensions of CS, BO and CF were found to be $32.93 \pm 8.83$ (minimum (min)-maximum (max): 5-50 points, median: 33.00), 18.39 \pm 6.91 (min-max: 2-42 points, median: 18.00 ), and $16.09 \pm 8.27$ (min-max: 0-49 points, median: 15.00), respectively. Furthermore, it was determined that while $77.8 \%$ of the participants were above the mean CS level, $62.8 \%$ of them were below the mean $\mathrm{BO}$ level and $87.3 \%$ of them were below the mean CF level. In the paired correlation analysis, CS was found to be moderately but negatively correlated with burnout $(\mathrm{r}=-0.572, \mathrm{p}=0.000)$ and weakly and negatively $(\mathrm{r}=-0.157, \mathrm{p}=0.000)$ correlated with CF. Burnout was correlated with CF above moderate and in the same direction $(r=0.622$, $\mathrm{p}=0.000$ ). (Table 2).

The statistical analysis of the CS, BO and CF levels of the healthcare workers who participated in the study according to demographic data and working conditions was presented in Table 3 .

In terms of CS, differences in age, marital status, title, field, professional working year, weekly working time, daily working hours and workmate's diagnosis with COVID-19 were found to be statistically significant ( $\mathrm{p}<0.05$ for each). The highest CS was found in those younger than 25 years $(35.29 \pm 8.71)$, single $(33.84 \pm 8.85)$, working as radiology technicians $(35.71 \pm 8.54)$ or in the radiology unit $(35.54 \pm 8.69)$, those with less than five years of professional experience $(37.35 \pm 8.04)$, those working over 45 hours a week $(34.50 \pm 8.89)$, those working 12 -hour shifts $(36.41 \pm 8.55)$ and those with no COVID-positive workmates $(33.71 \pm 8.71)$.

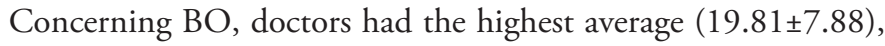
and we found the difference between professions to be statistically significant. Healthcare workers in the COVID-19 intensive care (20.87 \pm 7.12$)$, those with six to ten years of professional experience

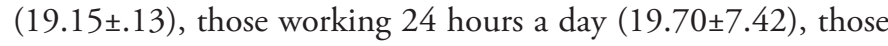
working in shifts $(19.63 \pm 7.37)$ and those with COVID-positive workmates $(19.76 \pm 7.15)$ had the highest mean BO score, and the difference between the groups was statistically significant ( $\mathrm{p}<0.05$ for each) (Table 3$)$.

The difference between the groups of gender, title, department, professional working year, and workmates' diagnosis with COVID-19 was statistically significant ( $\mathrm{p}<0.05$ for each) when it came to CF. The highest CF was seen in women $(16.17 \pm 8.09)$, Emergency Medical Technician (EMT)-paramedics $(17.85 \pm 8.88)$, those working in family medicine and community health $(18.31 \pm 7.68)$, those with six to ten years of professional experience (16.82 \pm 8.72 ), and healthcare workers with COVIDpositive workmates $(17.11 \pm 8.49)$ (Table 3).

\section{Discussion}

This study showed that during the COVID-19 pandemic to date, while $77.8 \%$ of healthcare workers were above the mean CS level, $62.8 \%$ of them were below the mean BO level and $87.3 \%$ of them were below the mean CF level. No research was found on healthcare workers' CS during the COVID-19 period throughout Turkey, and similar results were found in a study 
Table 1. Demographic data of the participants and descriptive statistics of working conditions

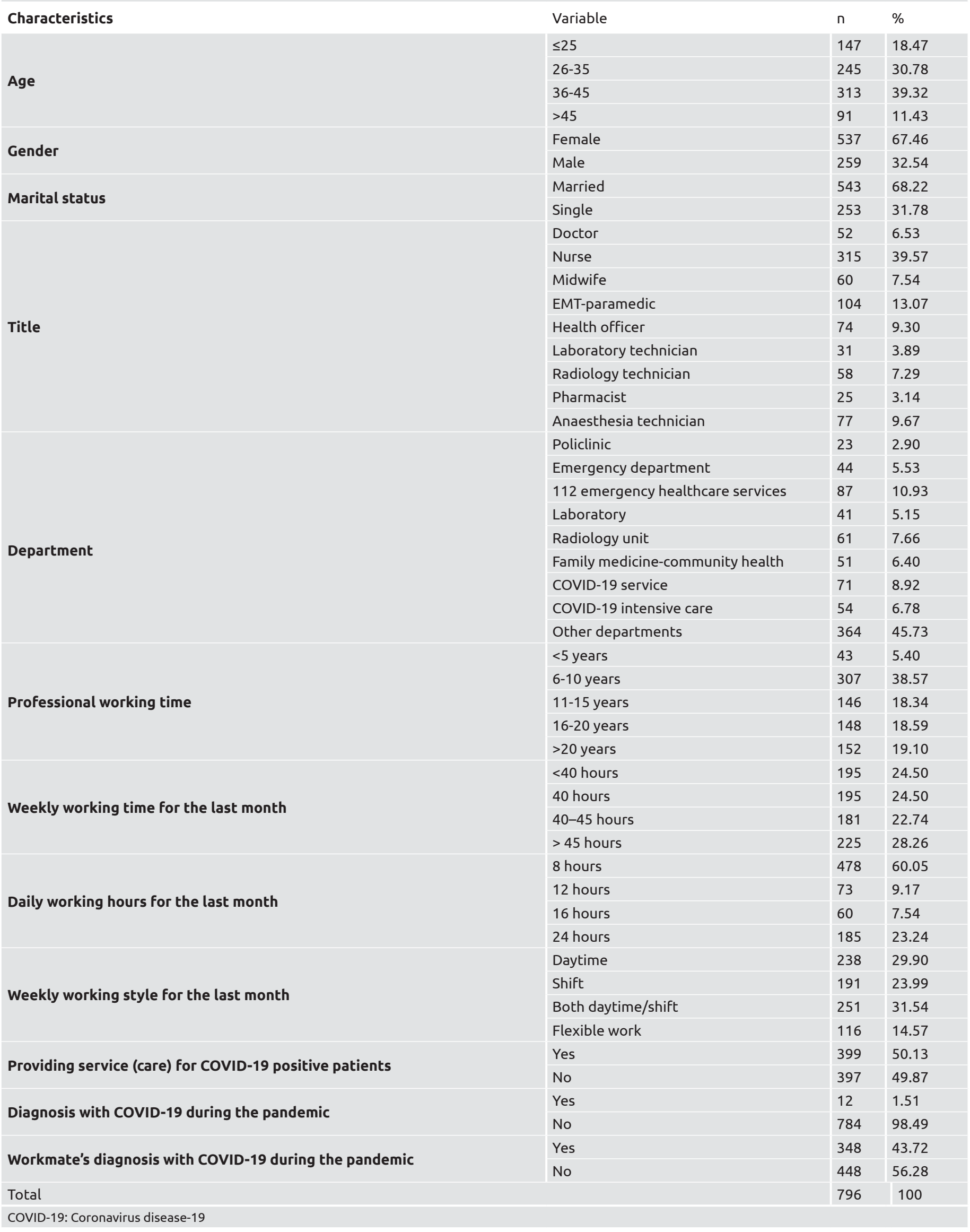


Table 2. Sub-dimensions of the Quality of Life scale for employees and the correlation of the sub-dimensions with one another

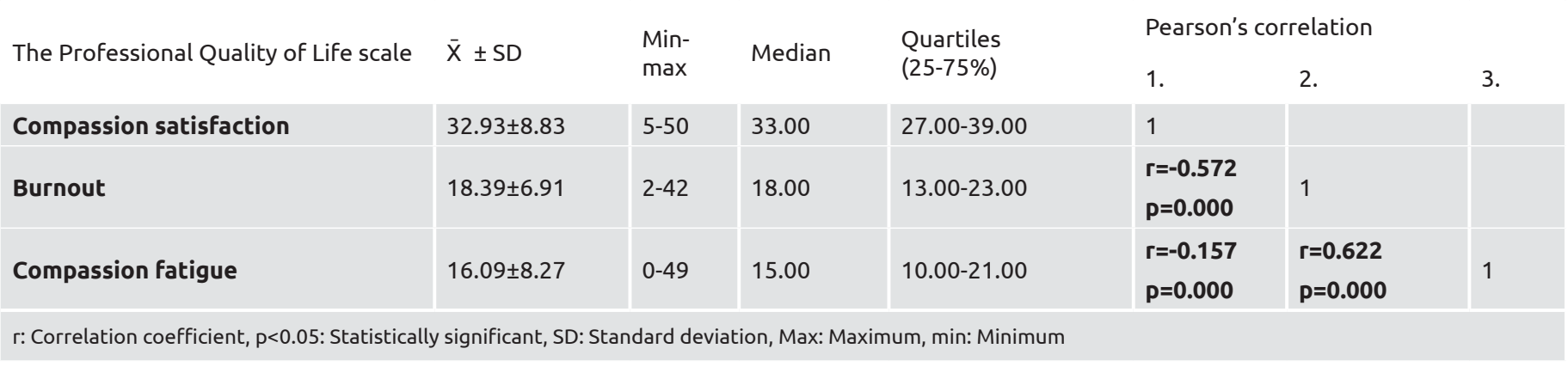

conducted using the same scale during the Chinese COVID-19 pandemic (20). However, in an Iranian study, healthcare workers' CS was found to be low (21). Similar studies on BO in Turkey demonstrated that healthcare workers had a moderate BO desensitisation score (22) and that healthcare workers were very optimistic during the COVID-19 period, despite experiencing stress and emotional exhaustion (8). Arpacioglu et al. (10) revealed that frontline healthcare workers in Turkey had high CF during the COVID-19 pandemic to date.

Our findings showed that most healthcare professionals were satisfied with their job and did not experience $\mathrm{BO}$ and $\mathrm{CF}$ during the period examined. The fact that Turkey experienced low case numbers, low mortality rates and low numbers of critically ill patients relative to other countries (23) might affectthis outcome. Other studies indicated that the severity of disease complications and high mortality rates in COVID-19 had adverse psychological effects on healthcare workers $(24,25)$. Healthcare workers might be positively affected by the increased employment of healthcare workers in Turkey during the pandemic, their perception of adequate working conditions (26), and the provision of adequate protective equipment, drugs and test materials (8). Mobilization was declared in the country at the time of the study, and with media announcements praising healthcare professions, healthcare workers felt supported, praised and motivated. This strengthened healthcare workers emotionally and psychologically and protected them from $\mathrm{BO}$ and $\mathrm{CF}$. This, in turn, ensured that CS was at a good level.

According to the results of this study, CS was higher in those younger than 25, single individuals, radiology technicians and other radiology workers, those with less than five years of professional experience and those working for 12-hour shifts. A similar study reported that age, gender, educational status and access to protective equipment affected CS during the COVID-19 process (21). Healthcare workers aged below 25 years of age might have higher CS because they were protected from exhaustion, they had fewer than five years of experience, accordingly worked in low-risk units, were generally single, and had less childcare or other responsibility. The fact that radiology technicians worked " $\mathrm{n}$ the background", with relatively little direct contact with patients, might also have a positive effect on CS.
In our study, the $\mathrm{BO}$ level of doctors and healthcare workers in COVID-19 intensive care were found to be higher. A similar study found that doctors experienced higher $\mathrm{BO}$, compared to nurses, during the pandemic (13). Matsuo et al. (11) reported that nurses and laboratory workers had higher levels of $\mathrm{BO}$ when compared to other workers. Doctors and nurses are at direct risk and therefore experience intense stress, while caring for COVID-19 patients. Due to the problems they experience in the working environment, these medical staff are negatively affected by physical, mental and social issues and face BO (27).

Intensive care units (ICUs) with critically ill COVID-19 patients are locations where healthcare workers face a high risk of infection, and therefore, they are required to wear advanced protective equipment. They are environments with high mortality rates, and in the case of this pandemic, the course and symptoms of the disease have sometimes been unknown (28). Therefore, healthcare workers in the COVID-19 ICUs are severely physically and psychologically affected and experience BO $(29,30)$. A similar study reported that those working in intensive care, emergency and COVID-19-related departments experienced higher levels of $\mathrm{BO}$ compared to some others (22). In this study, $\mathrm{BO}$ was higher in those with six to ten years of professional experience and those working 24-hour shifts. Contrary to these results, another study reported that healthcare workers with fewer working years had higher levels of $\mathrm{BO}$ (11). The Psychiatric Association Mental Trauma and Disaster Study Unit's Guide for the Protection of Healthcare Workers from Burnout during the COVID-19 Pandemic indicates that the working hours of healthcare workers, especially in the COVID-19 intensive care and services, should not be unusually long (31). Factors such as longer working hours, the number of COVID-19 patients being treated, and limited logistical support were associated with mental problems among staff (25). Furthermore, the International Nurses Association's guide states that senior nurses should be employed, especially in places such as COVID-19 ICU (32). Therefore, working in COVID-19 ICU might contribute to $\mathrm{BO}$ among senior healthcare workers with ten years of working experience.

According to this study, CF levels were higher in women, and those working in EMT-Paramedic, Family Medicine and Community Health departments. These results are consistent with the existing literature (10). CF is the mood of a person 
Table 3. Statistical analysis of compassion satisfaction (CS), burnout (BO) and compassion fatigue (CF) according to demographic data and working conditions $(n=96)$

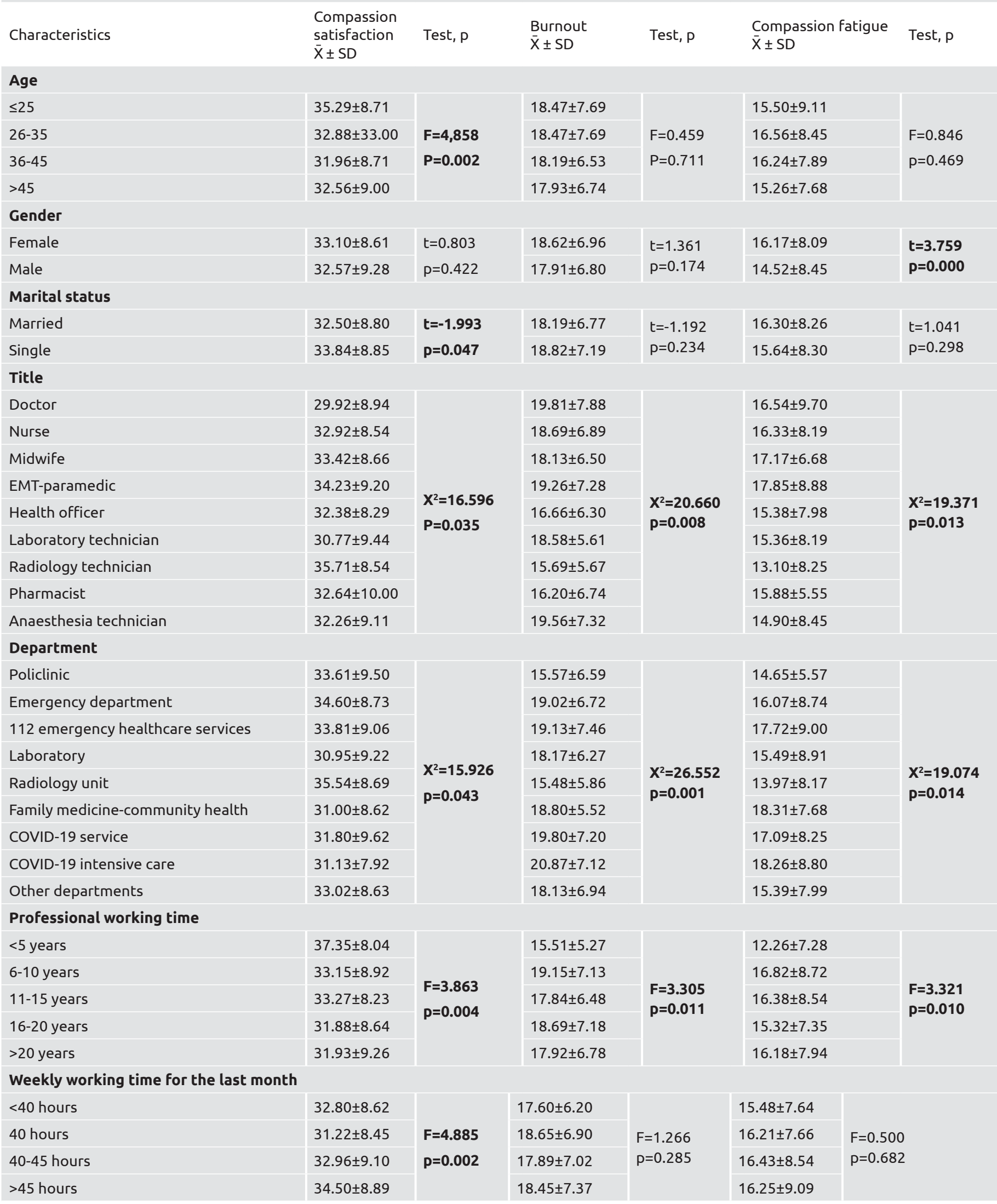


Table 3. Continued

\begin{tabular}{|c|c|c|c|c|c|c|}
\hline Characteristics & $\begin{array}{l}\text { Compassion } \\
\text { satisfaction } \\
\bar{X} \pm S D\end{array}$ & Test, $\mathrm{p}$ & $\begin{array}{l}\text { Burnout } \\
\bar{X} \pm S D\end{array}$ & Test, p & \multicolumn{2}{|c|}{$\begin{array}{l}\text { Compassion fatigue } \\
\bar{X} \pm S D\end{array}$} \\
\hline \multicolumn{7}{|c|}{ Daily working hours for the last month } \\
\hline 8 hours & $32.59 \pm 8.86$ & \multirow{3}{*}{$\begin{array}{l}F=4.227 \\
p=0.006\end{array}$} & $17.87 \pm 6.49$ & \multirow{3}{*}{$\begin{array}{l}F=3.477 \\
p=0.016\end{array}$} & $15.96 \pm 8.04$ & \multirow{3}{*}{$\begin{array}{l}F=2.284 \\
p=0.078\end{array}$} \\
\hline 12 hours & $36.41 \pm 8.55$ & & $18.99 \pm 7.62$ & & $17.07 \pm 9.63$ & \\
\hline 16 hours & $32.73 \pm 6.84$ & & $17.82 \pm 7.16$ & & $13.85 \pm 7.68$ & \\
\hline \multicolumn{7}{|c|}{ Weekly working style for the last month } \\
\hline Daytime & $32.07 \pm 8.76$ & \multirow{3}{*}{$\begin{array}{l}F=2.210 \\
p=0.086\end{array}$} & $18.19 \pm 6.39$ & \multirow{3}{*}{$\begin{array}{l}F=3.992 \\
p=0.008\end{array}$} & $16.10 \pm 8.13$ & \multirow{3}{*}{$\begin{array}{l}F=2.481 \\
P=0.060\end{array}$} \\
\hline Shift & $32.58 \pm 9.27$ & & $19.63 \pm 7.37$ & & $17.41 \pm 9.03$ & \\
\hline Both daytime/shift & $34.05 \pm 8.49$ & & $18.33 \pm 7.09$ & & $15.42 \pm 8.08$ & \\
\hline No & $33.13 \pm 8.36$ & $\begin{array}{l}t=-0.650 \\
p=0.516\end{array}$ & $17.96 \pm 6.54$ & $\begin{array}{l}t=1.758 \\
p=0.079\end{array}$ & $15.62 \pm 7.98$ & $\begin{array}{l}t=1.624 \\
p=0.105\end{array}$ \\
\hline \multicolumn{7}{|c|}{ Diagnosis with COVID-19 during the pandemic } \\
\hline Yes & $30.00 \pm 9.38$ & \multirow{2}{*}{$\begin{array}{l}Z=-1.016 \\
p=0.309\end{array}$} & $17.00 \pm 6.59$ & \multirow{2}{*}{$\begin{array}{l}Z=-0.398 \\
p=0.691\end{array}$} & $15.25 \pm 6.66$ & \multirow{2}{*}{$\begin{array}{l}Z=-0.036 \\
p=0.971\end{array}$} \\
\hline No & $32.98 \pm 8.82$ & & $18.41 \pm 6.91$ & & $16.11 \pm 8.30$ & \\
\hline \multicolumn{7}{|c|}{ Workmate's diagnosis with COVID-19 during the pandemic } \\
\hline Yes & $31.92 \pm 8.90$ & $\mathrm{t}=-2.857$ & $19.76 \pm 7.15$ & \multirow{2}{*}{$\begin{array}{l}t=5.020 \\
p=0.000\end{array}$} & $17.11 \pm 8.49$ & \multirow{2}{*}{$\begin{array}{l}t=3.074 \\
p=0.002\end{array}$} \\
\hline No & $33.71 \pm 8.71$ & $p=0.004$ & $17.32 \pm 6.52$ & & $15.30 \pm 8.03$ & \\
\hline
\end{tabular}

$\bar{X}$ : Arithmetic mean, SD: Standard deviation, F: ANOVA, t: Independent Samples T-Test, X2: Kruskal-Wallis test, Z= Mann-Whitney U Test, $p<0.05$ : Statistically significant

arising from experiencing stressful events in their line of work. The COVID-19 pandemic constantly exposes healthcare workers to stress. Some studies reported that female healthcare workers experienced more psychological problems and were more emotionally affected than their male counterparts during the difficult pandemic process $(1,8)$. EMT-paramedics work in conditions requiring rapid intervention in complex and stressful settings. Primary care workers and emergency service providers are healthcare workers who admit COVID-19 patients for the first time. Moreover, they provide services to society as a whole, without knowing who has COVID-19. Therefore, these workers may develop CF by working under constant stress.

According to our results, $\mathrm{BO}$ and $\mathrm{CF}$ were high and CS was low in healthcare workers who had workmates diagnosed as having COVID-19. The fact that healthcare workers' workmates were diagnosed as having COVID-19 might negatively affect them and caused them feel stress by highlighting the possibility that their workload would increase, or that they too might be infected and infect their families. Therefore, we found that workmates' diagnosis with COVID-19 reduced the CS of healthcare workers by causing $\mathrm{BO}$ and $\mathrm{CF}$.

\section{Study Limitations}

The study results and the reliability of the scale used were limited to the responses and sample size of the healthcare workers who participated in the study. The sample of this study consisted of health professionals working in Turkey. Although our sample size was sufficient, we could not reach to an equal number of health professionals working in all regions of Turkey. This was our most important limitation in this study. Also, it was a limitation that the evaluations were not supported by clinical examinations. In subsequent studies, clinical psychiatric examinations of the participants can be performed. There is a need for larger and more universal sample groups to obtain more detailed results.

\section{Conclusion}

This study evaluated healthcare workers' CS, BO and CF levels and their influencing factors during the four months of the COVID-19 pandemic in Turkey. We also determined that the title, professional working time, department and workmates' diagnosis with COVID-19 affected the CS, BO and CF levels of healthcare workers. We saw that the number of cases was low and the number of inpatients in health institutions was less in the fourth month of the pandemic throughout the country compared to the present day. This situation potentially led to good CS, BO and CF levels among healthcare workers. However, the psychological state of healthcare workers may change depending on the uncertainty of the pandemic process, the number of cases and the density of hospitals. Therefore, we recommend that $\mathrm{CS}, \mathrm{BO}$ and $\mathrm{CF}$ levels of healthcare workers be continuously evaluated and compared to previous ones, so that the necessary arrangements can be made and implemented as soon as possible. 


\section{Ethics}

Ethics Committee Approval: Permission was obtained for the study from the Ministry of Health (2020-05-21T15_40_06) and KTO Karatay University Medicine and Non-Medical Device Research Ethics Committee (2020/023).

Peer-review: Externally and internally peer reviewed.

\section{Authorship Contributions}

Concept: A.Y., Design: A.Y., B.Ö., Data Collection or Processing: A.Y., F.B., Ö.E., Analysis or Interpretation: F.B., A.Y., Ö.E., Literature Search: A.Y., F.B., B.Ö., Writing: A.Y., Ö.E.

Conflict of Interest: No conflict of interest was declared by the authors.

Financial Disclosure: The authors declared that this study received no financial support.

\section{References}

1. Liu CY, Yang YZ, Zhang XM, Xu X, Dou QL, Zhang WW, et al. The prevalence and influencing factors in anxiety in medical workers fighting COVID-19 in China: A cross-sectional survey. Epidemiol Infect 2020;148.

2. World Health Organization (WHO). Coronavirus disease (COVID-19) situation report-108. 2020 [cited 2020 Jun 8] Available from: URL: https://www.who.int/docs/defaultsource/ coronaviruse/situationreports/20200507covid-19_sitrep108.

pdf?sfvrsn=44cc8ed $8 \_2$

3. Wu Y, Wang J, Luo C, Hu S, Lin X, Anderson AE, et al. A Comparison of Burnout Frequency Among Oncology Physicians and Nurses Working on the Frontline and Usual Wards During the COVID-19 Epidemic in Wuhan, China. J Pain Symptom Manage 2020;60(1):e60-5. doi.org/10.1016/j.jpainsymman.2020.04.008

4. Zhang Y, Ma ZF. Impact of the COVID-19 pandemic on mental health and quality of life among local residents in Liaoning Province, China: A cross-sectional study. Int J Environ Res Public Health 2020;17.

5. Aşkın R, Tan Dinsel E, Baş A. Coping with the coronavirus (COVID-19) pandemic. Eur Res J 2020;6:365-9.

6. Cai H, Tu B, Ma J, Chen L, Fu L, Jiang Y, et al. Psychological impact and coping strategies of frontline medical staff in Hunan between January and March 2020 during the outbreak of coronavirus disease 2019 (COVID) in Hubei, China. Med Sci Monit 2020;26:1-16.

7. Rana W, Mukhtar S, Mukhtar S. Mental health of medical workers in Pakistan during the pandemic COVID-19 outbreak. Asian J Psychiatr 2020;51:102080.

8. Özdemir Ş, Kerse G. The effects of COVID-19 process on health care workers: Analysing of the relationships between optimism, job stress and emotional exhaustion. Int Multidiscip J Soc Sci 2020;9:178-201.

9. Muller AE, Hafstad EV, Himmels JPW, Smedslund G, Flottorp S, Stensland SØ, et al. The mental health impact of the covid-19 pandemic on healthcare workers, and interventions to help them: A rapid systematic review. Psychiatry Res 2020;29:113441.
10. Arpacioglu S, Gurler M, Cakiroglu S. Secondary Traumatization Outcomes and Associated Factors Among the Health Care Workers Exposed to the COVID-19. Int J Soc Psychiatry 2020;1-6.

11. Matsuo T, Kobayashi D, Taki F, Sakamoto F, Uehara Y, Mori N, et al. Prevalence of Health Care Worker Burnout During the Coronavirus Disease 2019 (COVID-19) Pandemic in Japan. JAMA Netw Open 2020;3:e2017271.

12. Zhang YY, Han WL, Qin W, Yin HX, Zhang CF, Kong C, et al. Extent of compassion satisfaction, compassion fatigue and burnout in nursing: A meta-analysis. J Nurs Manag 2018;26:810-9.

13. Ruiz-Fernández MD, Ramos-Pichardo JD, Ibáńez-Masero O, Cabrera-Troya J, Carmona-Rega MI, Ortega-Galán ÁM. Compassion fatigue, burnout, compassion satisfaction and perceived stress in healthcare professionals during the COVID-19 health crisis in Spain. J Clin Nurs 2020;:1-10.

14. Hofmeyer A, Taylor R, Kennedy K. Fostering compassion and reducing burnout: How can health system leaders respond in the Covid-19 pandemic and beyond? Nurse Educ Today 2020;94.

15. Türkiye Cumhuriyeti Sağlık Bakanlığı [Republic of Turkey Ministry of Health]. COVID-19 Situation Report [Internet]. Sağlık İstatistikleri Yıllığı 2019 [Internet] 2020 [cited 2020 Dec 16]. Available from URL: https://dosyamerkez.saglik.gov.tr/Eklenti/39024,haberbulteni-2019pdf.pdf?0

16. Yeşil A, Ergün Ü, Amasyalı C, Er F, Nihal Olgun N, Aker AT. dity and Reliability of the Turkish Version of the Professional Quality of Life Scale. Nöro Psikiyatr Arşivi 2010;47:111-7.

17. Günüşen NP, Wilson M, Aksoy B. Secondary Traumatic Stress and Burnout Among Muslim Nurses Caring for Chronically Ill Children in a Turkish Hospital. J Transcult Nurs 2018;29:146-54.

18. Stamm B. The ProQOL manual: The Professional Quality of Life Scale: Compassion Satisfaction, Burnout and Compassion Fatigue/ Secondary Trauma scales. Pocatello Idaho State Univ Sidran Press 2005.

19. Tabachnick BG, Fidell LS. Using Multivariate Statistics. Multivar Stat 2013;1-14.

20. Zhou Q, Lai X, Wan C, Zhang X, Tan L. Prevalence and impact of burnout, secondary traumatic stress and compassion satisfaction on hand hygiene of healthcare workers in medical aid team during COVID-19 pandemic 2020;1-16.

21. Zhang SX, Liu J, Afshar Jahanshahi A, Nawaser K, Yousefi A, Li J, et al. At the height of the storm: Healthcare staff's health conditions and job satisfaction and their associated predictors during the epidemic peak of COVID-19. Brain Behav Immun 2020;87:144-6.

22. Sahin T, Aslaner H, Olguner Eker Ö, Gökçek MB, Doğan M. A Questionnaire Study Effect of COVID-19 Pandemic on Anxiety and Burnout Levels in Emergency Healthcare Workers. Int J Med Sci Clin Invent 2020;7:4991-5001.

23. Türkiye Cumhuriyeti Sağlık Bakanlığı [Republic of Turkey Ministry of Health]. COVID-19 Situation Report [Internet] 2020 [cited 2020 Jul 27]. Available from: https://covid19.saglik. gov.tr/Eklenti/37743/0/covid-19-situation-report-v4pdf.pdf?_ tag1=1BBBA277D9AA5225230FFF995ECE6DF16684F1E6 
24. Baud D, Qi X, Nielsen-Saines K, Musso D, Pomar L, Favre G. Real estimates of mortality following COVID-19 infection. Lancet Infect Dis 2020;20:773.

25. Li Y, Wang H, Jin XR, Li X, Pender M, Song CP, et al. Experiences and challenges in the health protection of medical teams in the Chinese Ebola treatment center, Liberia: a qualitative study. Infect Dis Poverty 2018;7:92.

26. Bostan S, Erdem R, Öztürk YE, Kılıç T, Yılmaz A. The effect of COVID-19 pandemic on the Turkish society. Electron J Gen Med 2020;17.

27. Talaee N, Varahram M, Jamaati H, Salimi A, Attarchi M, Kazempour $\mathrm{M}$, et al. Stress and burnout in health care workers during COVID-19 pandemic: validation of a questionnaire. Journal of Public Health (Germany) 2020; Available from URL: https://www.ncbi.nlm.nih. gov/pmc/articles/PMC7275852/pdf/10389_2020_Article_1313.pdf

28. Alharbi J, Jackson D, Usher K. Compassion fatigue in critical care nurses. An integrative review of the literature. Saudi Med J 2019;40:1087-97.

29. Azoulay É, Beloucif S, Beloucif S, Guidet B, Guidet B, Pateron D, et al. Admission decisions to intensive care units in the context of the major COVID-19 outbreak: Local guidance from the COVID-19 Paris-region area Crit Care 2020;24:1-6.

30. Hu D, Kong Y, Li W, Han Q, Zhang X, Zhu LX, et al. Frontline nurses' burnout, anxiety, depression, and fear statuses and their associated factors during the COVID-19 outbreak in Wuhan, China: A large-scale cross-sectional study. E Clinical Medicine 2020;24.

31. Türkiye Psikiyatri Derneği Ruhsal Travma ve Afet Çalışma Birimi [Turkish Psychiatric Association Mental Trauma and Disaster Study Unit]. Covid-19 Salgınında Sağlık Çalışanlarının Tükenmişlikten Korunma Rehberi [Guide for the Protection of Healthcare Workers from Burnout during the COVID-19 Pandemic] 2020 [cited 2020 May 5]. Available from URL: https://www.psikiyatri.org.tr/ uploadFiles/14202016552-TukenmislikCOVID.pdf 32.

32. International Council of Nurses (ICN).World health professions alliance calls on g20 to protect health workers facing COVID-19 [Internet] 2020 [cited 2020 Jun 9]. Available from URL: https:// www.icn.ch/news/world-health-professions-alliance-calls-g20protect-health-workers-facing-covid-19. 